\title{
Negative externalities of food production: discourses on the contested Norwegian aquaculture industry
}

\author{
Erling A. N. Christiansen ${ }^{1}$ \\ University of Oslo, Norway
}

\section{Introduction}

In this article, I undertake a critical discourse analysis on how divergent perceptions of human/nature relations exist in the industrial practice of Atlantic salmon farming in Norway. I investigate specifically how present and future external costs (henceforth labeled negative externalities) are talked about, understood and framed. Understanding divergent perceptions of nature is important for analysis of political ecology questions, and is arguably the key building block that ought to unite all geographers (Castree 2005).

While the practice of Atlantic salmon farming is extensively analyzed from both financial and biological perspectives, there is no literature on how discourses on the industry are constructed through the dialectics existing between particular groups and actors, and the language they accept and apply. A background presentation of both methodological and industry specific issues is necessary, and accounted for in sections two to five. The analysis of discourses themselves in section six. In section seven, these findings and concepts are discussed and deconstructed, before a realist approach is offered in section eight. Section nine sums up the analysis, including a schematic overview of the various interest groups, premises and arguments of the respective discourses.

\section{Norwegian aquaculture/sea farming}

The Norwegian marine farming sector consists of some 200 companies, sharing approximately 1,000 permits for grow-out sites in seawater, and some 250 permits for smolt-rearing facilities (Aarset and Jakobsen 2008).. Over $90 \%$ of marine farmed fish in Norway are breeds of Atlantic Salmon (Salmo salar) (Marine Harvest 2011). In 2010, Atlantic salmon generated the most government revenue of any domestic species in Norway (Taranger et al. 2010), totaling an export value of more than 30 billion Norwegian kroner (US\$ 5 billion). In 2010, some $10 \%$ of the total value of exports from mainland Norway was marine farmed fish (Norwegian Ministry of Fishery and Coastal Affairs 2010). More than 95\% of this was exported. In short, farmed salmon has become a major Norwegian commodity. At present there is salmon farming activity in some 150 out of 430 Norwegian municipalities.

Most innovations have at least one thing in common: the original invention took place much earlier in history than commonly believed (Diamond 1997). Marine farming was considered to be a Norwegian innovation when the possibility for farming trout and salmon in seawater net-pens was proven successful in 1969, although aquaculture techniques date back four millennia (Berge 2002; Johansson 2004). The Norwegian aquaculture "pioneer" environment of the 1950s and 1960s had a horizontal and fragmented firm structure, marked by creative and entrepreneurial objectives (Aslesen et al. 2002). It was the result of decades of local experimentation and incremental development of technologies.

The inexperienced Norwegian industry assiduously delivered far more ingenious and plausible solutions for salmon farming than its Scottish competitor, which had superior scientific knowledge and aquaculture research institutions in the post-World War II decades (Needham 1986). New ideas flourished and Norwegian "know-how" (practical and experimental knowledge) trumped Scottish "know-why" (scientific knowledge) in terms of successful innovations. In addition to an advantageous institutional mentality, Norwegian coastal regions facilitated regional and competitive advantages in terms of wellestablished infrastructure; suitable sea water-temperature; a fjord environment protected from extreme weather conditions; and a proliferation of government subsidized, decentralized settlements (Brox 1989). Whether the physical or the social institutions were more important for the spread of Atlantic salmon farming in the 1970s is debatable, but certainly the industry has changed over 40 years and there has been an evolution of policy and of various regulation schemes (Aslesen et al. 2002; Aarset and Jakobsen 2008).

Nonetheless, the industry is still characterized as one of "'know-how" more than "know-why" (Fagerberg et al. 2009; Magnussøn 2011). For example, veterinarians complain that the administrators of sea farming firms rarely attend seminars on new aquaculture methods, even though attendance is mandatory according to the Norwegian Aquaculture Act (Poppe 2010). An indifference towards scientific inputs in the Norwegian sea farming environment may generate positive effects (more creativity) and negative effects (poor understanding of biological regularities). The communication director of Marine Harvest (the world's largest salmon farming company), Jørgen Christiansen confirmed this impression when he said, "there hardly

\footnotetext{
${ }^{1}$ Erling A. N. Christiansen, PhD student, Department of Sociology and Human Geography, University of Oslo, N-0316 Oslo, Norway. E-mail: erling.christiansen "at" sosgeo.uio.no. Thankyou to the referees and editors.
} 
exist formally trained engineers in the Norwegian salmon farming industry." ${ }^{2}$ Indeed the undergraduate degree program in Aqua-engineering at Bergen University College was terminated in 2011 due to a lack of students.

\section{Externalities as a financial and physical concept}

In terms of sustaining a healthy ecology in a given region, the more robust and diverse the activities of aquaculture and agriculture, the more prepared we are to face risks and to enter a future of unknown, influential events. As one of few writers who link finance and ecology, Nassim Nicholas Taleb advocates the importance of robustness to avoid negative externalities. His bestseller The Black Swan - the impact of the highly improbable (Taleb 2007) and some 10 peer-reviewed articles deal with robustness and the redundant capacities of healthy firms and also environments.

Negative externalities are costs that are not financially internalized by responsible actors. How can we measure an externality? In mainstream economics, it is argued that the risk (probability multiplied by impact) of specific, future externalities can be analyzed mathematically (Slovic 1987). However such assumptions understate the prevalence of incalculable risk (also known as knightian uncertainty) and what the financial literature labels "fat tails" or "black swans", i.e. unexpected, large deviations from the average event (Knight 1921; Mandelbrot and Hudson 2008; Taleb 2007). Negative externalities are often included in graphs where abatement costs are perceived to alleviate environmental damage according to the market's assumption of the marginal costs and benefits of both past, present and future activities (Hanley, Shogren and White 2007). Beck (1992) denotes this risk-assessment methodology of mainstream economics as a new form of modernity, highlighted by the ubiquitous "zero accident vision" policies, where the rather futile attempt is to not only minimize risk, but to eliminate it. In the commercial sector, negative externalities cannot be adequately internalized by responsible firms. The Norwegian government has identified five main categories where salmon farming negatively affects the environment: genetic interaction and escape; disease; pollution and emissions; area utilization; feed and feed resources. Pollution and emissions and area utilization generate negative externalities primarily at the local or regional level, whereas genetic interaction/fish escape, disease and feed and feed resources, negatively impact the environment and/or actors at larger geographical scales (Taranger et al. 2010; Institute of Marine Research 2011). I leave area utilization out of the analysis as it relates more to the aesthetics of fish farms than externalities. Feed resources are outside of the scope of this article since they concern externalities of Brandt-line divides, as well as nutritional concerns for consumers. Problems of local emissions and the diffusion of pathogens, however, evoke many contemporary discursive discussions, and will be given particular attention. The analysis involves how actors talk about and understand externalities.

Over the past seventy years in Norway, hydroelectric power installations and the parasite Gyrodactylus salaris have significantly reduced the returning Atlantic salmon populations (Berg 1986). In several rivers, a certain population threshold is only sustained due to human hatcheries. At other locations, salmon populations have already collapsed. The reduction in the numbers of salmon over the last few decades, however, is linked to increasingly virulent pathogens that thrive in net pens with high-density salmon populations, which allow up to $25 \mathrm{~kg}$ of salmon per square meter. The degree of sea lice and other pathogens varies between grow-out sites, and in line with this, degrees of conflicts between different interest groups also vary. More importantly, emissions from salmon farms - faeces, medicines and feed spills, negatively impact the surrounding environment and local fisheries. Consequently, it is important to note that a) we face an uncertain future for Norwegian fjord environments and b) some locations are more susceptible and thus involved in deeper discursive conflicts than others. Marine Harvest acknowledges that "for several pathogens/diseases there are either limited effective cures or limited therapeutic options" (Marine Harvest 2011:59). It follows that environmental costs are necessary attributes of salmon farming. Whether these costs will remain externalities or be internalized by the responsible actors is the subject of discursive disagreement.

Blaikie (1989) points out that alleviation of negative externalities cannot be properly conducted without an emphasis on the regional dimension. Causal relations for externalities are more traceable at a regional than global level. Accordingly, the empirical research of Ostrom et al. (1999) and Ostrom (2005) on local and informal agreements suggest that the tragedy of the commons (characterized by local, negative externalities; Hardin 1968) can be circumvented without succumbing to the above-mentioned abatement cost calculations of mainstream economics. The solution resides in reinforcement of local/regional community "consensus" agreements, where technologies are chosen according to local virtues and tacit knowledge rather than centralized administrative procedures of either states or transnational companies. Ostrom discovered that resource scarcity at the local level creates cooperation rather than conflict in autonomous communities. She thus contradicts the very foundation of (neo)classical economics, i.e. the mercantilist premise of scarcity of natural resources. In a critique of the same (neo)classical economics tradition, Elster (2009) argues that it is saturated with excessive ambitions, rather than sincere, contextual empirical work, and concludes that it constitutes (p. 9) "... something of a scandal."

\footnotetext{
${ }^{2}$ March 28th 2012, seminar, Oslo.
} 
Looking at externalities at the regional level demands a specific premise, i.e. the existence of geographical scales. Smith (1992:73) expresses the following nuance: "With a concept of scale as produced, it is possible to avoid on the one hand the relativism that treats spatial differentiation as a mosaic, and on the other to avoid a reified and uncritical division of scales that repeats a fetishism of space." If we were to reach the point where human activities are confronted with a hypothetical "last Atlantic salmon argument" - i.e. that the continuation of specific regional activities with negative externalities were the cause of the elimination of returning Atlantic salmon in the last locations of their breeding rivers, the problem, 'scales up' from the region to become global in terms of the moral obligations towards sustaining a (sub)species. ${ }^{3}$

\section{What is soft constructionism?}

Inspired by substantial work in political ecology (Woolgar 1988; Berkes 1999; Sullivan 2000; Watts, Robbins and Peet 2010), a realist foundation (the belief that reality exists independently of observers) must underpin any effort to deconstruct (to look for the driving motivations behind) human activities. A discourse around salmon farming must also be traceable to the real decisions made about externalities of contemporary food production in this context (Adger et al. 2001). Blaikie (1996; 1999; 2001) underpins this point, emphasizing that post-structural writers identify certain hegemonic concepts, but do not distinguish between real and locally solvable environmental problems, (such as soil erosion, domestic species epidemics and loss of biodiversity from specific, local practices) and diffuse, global, political, and environmental agendas on the other. ${ }^{4}$ Sullivan (2000: 32) argues for integration of the natural and social sciences: "I suggest, therefore, that there might be much room for conceptual exchange between a biophysical science which embraces both form (i.e. structure) and change (i.e. innovation) in living complexes, and an actor-oriented applied social science grappling with conflict between local dynamics and national or global structures."

Robbins (2004) labels Sullivan's integration "soft constructionism." Social institutions construct the norms and habits of actors, but not underlying biological realities (John Searle provides the best accounts, see Searle 1995, 2010). When Bourdieu concludes that (1977:164) "Every established order tends to produce the naturalization of its own arbitrariness", he sidestepped the issue that some orders are ontologically less arbitrary, and more 'grounded', than others. If this point is not important, social science has no purpose. Social scientists should therefore be aware of local and concrete environmental issues rather than diffuse ones less 'anchored' to reality and to material concerns. As an example: despite significant and reliable data suggesting how a few practices stand out as substantially more destructive for the quality of agricultural soils than others, post-structural research is not good at alleviating real, physical challenges through concrete measures to combat soil erosion (Montgomery 2003). The approach of Lacan, one of the key reference points in poststructural thought, is too concerned with the arbitrariness and origin of language to have a proper defense against reactive arguments relating to causal uncertainty (Fairclough et al. 2002). In other words the nominal deconstruction of hegemonies is no longer meaningful as an alternative to existing power structures faced with hegemonic science discourse (Sullivan 2000). Whether some discourses on negative externalities of salmon farming have more sound and coherent logic than others is addressed in section six.

\section{Methodology}

The analysis presents the essence of debates on salmon farming found in Norwegian newspapers (both local, national and industry-specific newspapers), in TV documentaries and conferences, and some of the core issues raised by parliamentary discussions and outspoken scientists. A wide range of sources are considered, and thereafter qualitatively selected as more or less relevant for the present topic of negative externalities. Scientists who are not frequently quoted or do not speak out publicly are poorly involved in discursive framing (beyond suppressing issues, as already noted). Each discourse is presented in a general context and specifically through important statements by leading actors. The statements are selected to illustrate the essence of the respective discourses.

A discourse should be understood as a way of collectively talking of and understanding specific aspects of activities, including "... assumptions about what there is, what is the case, what is possible, what is necessary, what will be the case, and so forth." (Fairclough 2003:55). No discourse, of course, is devoid of the power of individual agency (Searle 2010). Rather, discourses should be seen as an interplay between the agency of individuals on the one hand and emerging and existing structures on the other (Fairclough et. al. 2002; Hodgson 2006; Benjaminsen and Svarstad 2010). That said, a discourse is not a collective subject, and should consequently not be treated as one. Unless only one discourse influences the development of policies and civil action, it is not fruitful to analyze a discourse as hegemonic. Rather, some discourses are "leaders" and others are "challengers". Similar co-existing discourses constitute a discursive order (Fairclough 1995).

Open debates about the consequences of salmon farming in Norway primarily take place in the media and at conferences hosted either by the industry itself, by NGOs or by governmental institutions. After

\footnotetext{
${ }^{3}$ See, for the political ecology of "The last Northern cod," McGuire (1997).

${ }^{4}$ See also Hulme (2010).
} 
qualitatively analyzing the debates that have intensified over the last few years, I have identified four, recurrent types of argument, which I introduce in section six and label:

- $\quad$ The high turnover discourse;

- The technology optimism discourse;

- The first nature discourse and,

- The traditionalist discourse

The inclusion of farmed salmon in derivatives (futures) financial markets must be kept in mind in the presentation of discourses below. The global order is increasingly enveloped by shareholder capitalism, i.e. optimization of debt-equity ratios on behalf of limited liability shareholders (Martin and Riel 2011). Power relations are increasingly skewed towards the benefit of those who are willing to play by the "rules of the game", or what Taleb (2007) describes as the "Soviet-Harvard style" (legitimized by the state, and directed by a financial elite).

\section{The discourse analysis}

\section{The high turnover discourse}

Statement I, by Anne Osland, member of Gullestadutvalget (Hardangerfjordseminaret, Øystese $05 / 05 / 2011)^{5}$ : A precondition for this report is that the industry is supposed grow. To be honest: we don't know very much about long-term consequences.

When actors argue that the primary responsibility of salmon farmers is to supply as much salmon to the market as possible, while ignoring external costs from the production, they speak themselves into a "high turnover discourse." High levels of debt (capital investments), input, turnover and output are all acknowledged as the stairway to a company's success. A high turnover is considered more important than a balanced ratio between inputs and outputs. In other words: if inputs are higher than outputs, a high turnover shields the inbalance through the convenient distinction between short-term and long-term liabilities. Until a crisis occurs, banks are satisfied with a high turnover alone - potential problems with overinvestment are postponed. But damage to the environment is also a form of debt. Just like monetary debt is externalized through inflation ("quantitative easing"), debt to the environment is externalized onto actors who do not benefit from it. Actors defending a high turnover discourse do not find this particularly problematic.

The discourse is both explicitly (through statements) and implicitly (through frames of information) conveyed through many official channels directed by Norwegian aquaculture organizations. As an example of the latter, two internet newspapers for fish farmers, investors and complementary industries, www.kyst.no and www.intrafish.no, present salmon farming in terms of financial benefit alone, by listing government tax revenues generated by the industry and international market rates for farmed salmon through forward and futures spot prices. They also list similar derivatives for input commodities such as vegetable oils for fish feeds. This stresses present value before both sustainability, quality of the product, or the real price of inputs (including external costs). Exchange value, derived from branding, marketing and so on, is thus perceived as a more convenient form of presentation than user value.

In The tragedy of the commons, Garret Hardin observed that in real life "incommensurables become commensurable" (1968: 1244). Actors defending a high turnover discourse have absorbed what follows logically from Hardin's above statement as their primary rationale - "that nice guys finish last." This is expressed candidly, such that negative externalities are partly understood as positive externalities if they yield higher demands for new capital investment in either rectification (of negative externalities) or innovation. Tveterås (2002) argues that environmental problems related to salmon farming actually stimulate innovations. Indefinite technological fixes to redeem symptoms generate demand for more and new products and redeem what David Harvey defines as the capital surplus absorption problem, i.e. the necessity for banks and firms to accumulate debt (investments) in order to avoid a reduction in their capital value (Harvey 2010). In September 2011, for example, the sea farming of Labridae (wrasse) experienced an economic breakthrough. The Labridae family are not utilized for human consumption, but for their capacity to consume the parasite sea lice affecting farmed salmon - they are farmed solely as a natural predator. It is an additional input cost to produce salmon, but not considered as such. The farming of Labridae has itself recently incurred disease problems, yielding a demand for even more technological fixes.

Within the high turnover discourse, then, negative externalities are not considered particularly problematic so long as they lead to increased utility for shareholders directly or indirectly - or become a

\footnotetext{
${ }^{5}$ Gullestadutvalget was a committee employed to write a report commissioned by the Norwegian government on the environmental consequences of salmon farming, and recommending an environmental strategy for Norwegian aquaculture.
} 
(short-term) addition to monetary value for Norwegian society. This is evident in the following statements. ${ }^{6}$ An adaptive logic operates: that "what happens happens, and we will deal with it somehow."

Statement II, by Rögnvalddur Hannesson, Professor Norwegian School of Economics (Dagens Næringsliv 26/10/2010): We should perhaps ask ourselves why we need wild salmon? If wild salmon gets in the way of the sea farming industry, then we must sacrifice wild salmon.... The industry creates great values and jobs along the entire (Norwegian) coast.

Statement III, by a representative of Marine Harvest, Norway's largest salmon farming company. (presentation at the Norwegian School of Economics, September $16^{\text {th }} 2011$, page 113): There are number of variables that are outside of farmers' control... Disease, escapement...

Statement IV, by Gustav Witzøe, Founder of Salmar ${ }^{7}$ (Dagens Næringsliv, 12/1/2011): The future of salmon farming is offshore. Salmon farming in closed systems is too costly and energy-inefficient to be commercially possible. If regulations demand closed systems to avoid escapes, Norway loses its advantage of sea water temperature. As an industry we should consequently work against closed systems.

The instrumental rationale of these arguments is illustrated by the way human modifications of environments are assessed in terms of their effects on human well-being. The logic follows David Ricardo's classical teleology, i.e. that human beings have a higher and less random end to their lives than the surrounding ecosystems (Stacey et al. 2000).

Statement V, by Sveinung Sandvik, FHL $^{8}$ (Dagens Ncringsliv 11/01/2011): The world does not look the way it did when God created it... Agriculture changed the way the world looks, so does aquaculture.

Statement VI, by Aina Walland, Director of Environment, FHL (Hardangerfjordseminaret, Øystese 05/05/2011): Sea farming is highly important for the Norwegian economy. All industries have large ecological footprints. Most Norwegians want a strong welfare state and a flat-screen TV. Therefore, they have to accept that industries change environments.

Although human modifications of environments and landscapes are assessed here from an anthropocentric perspective, there are actors defending a high turnover discourse who apply an adaptive logic even more candidly. They provide evolutionary arguments for why the externalities of salmon farming could have beneficial effects on the natural selection of wild salmon, insofar as the "weakest" are killed off by the increasingly virulent sea lice emerging from the industry:

Statement VII, by Inge Bringsvor, Founder Bringsvor Salmon (Dagens Ncringsliv 22/03/2011):

Salmon lice are good for evolution. Escaped farmed salmon creates excellent evolutionary competition for wild salmon.

Interestingly, high turnover arguments are also used to advocate for stronger sanctions on the industry. A concern for the reduced turnover of industries that suffer from the negative externalities of salmon farming is suggested in the following conclusion, where the loss of jobs and income among businesses external to the sea farming sector, such as fjord fisheries and river angling, are taken into account:

Statement VIII, by Liu et al. (2010:417): Clearly, the (aquaculture) sector does not compensate the wild sector for the imposed negative external costs. There is also a strong argument that the salmon sector should pay a resource rent like the Norwegian oil and hydroelectric power production sectors.

This language exploits the fuzzy causality between past, present and future events by referring to science in the future tense. A recurrent statement of the discourse, particularly employed by outspoken owners or employees of the salmon farming industry is: "we need more science to prove this." Existing science is thus never sufficient within the adaptive logic of the high turnover discourse. The candid negation of current

\footnotetext{
${ }^{6}$ All statements not originally expressed in English were translated by the author.

${ }^{7}$ This is the third largest sea farming company operating in Norway, producing 65,000 tons of salmon in 2009.

${ }^{8}$ FHL is the abbreviation denoting the official Norwegian Seafood Federation.
} 
science conveniently circumvents confrontations, as actors implicitly postpone such entrapments to a point in the future when science is even more saturated with knowledge about fish farming.

\section{The technology optimism discourse}

Statement IX, by Trond Giske, Norwegian Minister of Trade and Industry (Government lecture 01/02/2011): Technology development involves risks and dangers, but we will face these with technology optimism.

Garret Hardin defined a technical solution "as one that requires a change only in the techniques of the natural sciences, demanding little or nothing in the way of change in human values or ideas of morality" (1968: 1243). What I label the "technology optimism discourse" is highlighted by a win-win attitude, in which new technology is talked of as the redeemer of present symptoms in congruence with continued expansion of the industrial practice in question. Such language is particularly prevalent among government and parliamentary representatives, where several contradictory interests are semantically cared for, equivalent to the logic Castree defines this as the "neoliberal, environmental fix" (2008).

Technological optimists avoid discussion of possibilities for structural change. Industrial sea farming and a symptom-free environment are perceived to eventually (at some undefined point in the future) coexist harmoniously at locations where there are currently environmental problems. The groups defending this discourse are particularly concerned with the future expansion and health of west-coast salmon production sites, fjords and rivers. The win-win attitude is exemplified by the following selected statements.

Statement $X$, by The Ministry for Fisheries and Coastal Affairs (2009): We want controlled growth, in parallel with the development of technologies which ensure environmental sustainability. (The statement thereafter goes on to list numerous technological fixes to solve/reduce negative externalities.)

Statement XI, by Erik Solheim, Norwegian Minister of Development and Environment (Conference on environmental regulations, Oslo, January 19th 2011): Even though we face challenges, the world is of course improving. Social standards are better today than in the 1950s. Environmental regulations are better in all sectors. The world is simply improving because we are increasingly enlightened.

Statement XII, by Sigve Nordrum, Vice President Aker BioMarine AS (Dagens Ncringsliv 22/12/2010): With new remedies for combating disease, aquaculture becomes sustainable.

Statement XIII, by Frank Asche, Professor University of Stavanger (Aftenposten 30/11/2010): New technology is necessary, but will also yield new problems... Gradually, we will solve more and more problems.

The technology optimism among central government and parliamentarians suggests a shared political commitment to productivity growth and increased capital investments in salmon farming. In the Norwegian parliament's debate on the status and prospects for Norwegian Aquaculture (February 17 ${ }^{\text {th }} 2011$ ), the most relevant issue for most speakers was how to make the industry sustainable and compatible with other taxpaying industries (particularly angler tourism). Nevertheless, out of 16 speakers in the debate, across all political parties, only solutions lying within the existing development path were discussed. Disagreements among the elected representatives related exclusively to the degree of technological regulation and types of technological fixes to combat negative externalities. Limitations on how much salmon that ought to be produced, either per unit or in total domestic volume, were hardly mentioned. The consensus was: tax-income from salmon farming exports means increased well-being for Norwegian citizens.

Statement XIV, by Christoffer Gravdahl Rønbeck, senior adviser at The Ministry of Fisheries and Coastal Affairs, (Hardangerfjorseminaret, Øystese 05/05/2011). The Ministry of Fisheries and Coastal Affairs trusts the market to come up with plausible technological inventions to solve present issues with sea farming. We will also consider the polluter-pays-principle.

Statement $X V$, by Lisbeth Berg-Hansen, Minister of Fisheries and Coastal Affairs (Klassekampen 18/02/2011): The goal of a sustainable strategy for aquaculture is that sea farming will not cause long-term changes in the genetics of wild salmon.

Statement XVI, in the Strategy for an Environmentally Sustainable Norwegian Aquaculture Industry (Norwegian Ministry of Fisheries and Coastal Affairs. 2009: 4): The causes of most escapes in recent years have been damage to installations, inadequate technical repair of the installations, human error, predators and predation through nets, collisions, poor inspection and working procedures, lack of control systems and lack of competence among salmon farmers. 
The Norwegian government position is technological optimism - admitting grave problems in the present, but trusting future technology to solve most, if not all of them. Note that the statement below by a leading official says "zero escapes" (incidentally, the official is also the owner of a salmon farm). This is where the technology optimism discourse truly departs from the high turnover discourse.

Statement XVII, by Liv Holmefjord, Director, Norwegian Directory of Fisheries (Hardangerfjordseminaret, Øystese 05/05/2011): With new technology we have a vision of zero escapes from salmon farming.

While actors supporting a high turnover discourse acknowledge indefinite technological fixes as benevolent contributors to the capital surplus absorption problem, they also imagine a future "end state" of technological success. Interestingly, the average, annual level of reported salmon escaping from salmon farms has not declined since measurements were initiated in 1989 (Diserud et al. 2010), and are even by most industry representatives acknowledged to be higher than reported. It is quite bold to envision zero escapes.

In the Strategy for an Environmentally Sustainable Norwegian Aquaculture Industry (Norwegian Ministry of Fisheries and Coastal Affairs. 2009:15), it is argued that fewer, larger production units with more individual salmon at each site will help combat pathogens. A few sentences later in the same strategy, however, it is argued that large production units must be limited with a stricter ceiling on the maximum numbers of salmon. The two regulatory solutions are contradictory, implying that the strategy has good intentions, but little will to change. Max Weber's Protestant Ethic seems to apply (Weber 2011[1905]). Seeking personal comfort on the one hand and empathetic intentions on the other, without an understanding of how to balance these, means certain rationales are expressed at the expense of others. Confusion, misunderstanding and unaccomplished goals prevail. This quote suggests the primary provider of technological solutions, the Institute of Marine Research, employs internal contradictions:

Statement XVIII, by Torbjørn Forseth, leader of the Norwegian Scientific Council for Salmon Management (Dagens Næringsliv 03/12/2011): Most scientists agree about the problem of escaped salmon, but the Institute of Marine Research has close links to the Ministry of Fisheries and Coastal Affairs and is therefore understating the remedies that are needed to combat environmental problems from salmon farming.

A reactive logic trusts codified, technological knowledge that will relieve the problems of an industry thus far dominated by "local experimentation." It is common among commentators within the discourse to compare the negative externalities of contemporary salmon farming with the pollution generated by the fish processing industry in the 1970s and 1980s. Stricter regulation was applied over time to processing firms, and it is expected among technology optimists that salmon farming will experience a similar, "benign" trend. But salmon farming struggles with living pathogens, not dead matter. Comparing the two industries is unconvincing at best and constitutes a fallacy of comparing incompatible sizes.

\section{The first nature discourse}

In Jonathan Franzen's novel Freedom (2010), the self-proclaimed nature-lover Walter Berglund compromises his integrity working for a mining corporation wanting to strip-mine coal in West Virginia before turning the land into a nature conservation reserve. Berglund is puzzled when local residents, who receive excellent financial compensation, are antagonistic towards his strategy. Unlike the local residents, Berglund has a two-dimensional world view. To him, nature is either pristine or impure. He does not conceive of the possibility of long-term economic activities that can be conducted without devaluing the quality of nature.

The narrative that there is a natural state of the world devoid of human influence; some kind of absolute baseline, an ecological climax unaltered by anything anthropogenic, is a first nature discourse. The concept has been given attention by several geographers (Castree 2005; Glacken 1967; Smith 1984). It is criticized by political ecologists as neo-colonial romanticism (Benjaminsen and Svarstad 2010; Maddox 2002; Hesse and MacGregor 2006; Robbins 2004). There are still a few untouched places such as remote underwater mountain ranges in the Pacific Ocean. However, these are seldom, if ever, the places to which a first nature discourse is applied. The first nature discourse sits primarily in the language of actors and organizations that desire the separation and protection of specific species and areas from selected economic activities in regions where there has been a long term human presence. Analytical criticism of financial structures (which are integral to the very same economic activities) is not part of the first nature discourse.

Elliot (1982) argues that once human beings have altered a geographical area, it has forever lost its natural value. Organizations such as World Wildlife Fund (WWF) and the Salmon Aquaculture Dialogue 
adopt a first nature discourse through their efforts to preserve and restore areas from the impact of humans. WWF, for example, accepts sea farming as long as it is kept in isolated areas. The Salmon Aquaculture Dialogue advocates for practices such as finders' fees for each escaped domestic salmon caught in the wild creating a common ground between both the industry and preservation movements. Neither organization try to alter the underlying structures that both de jure and de facto legitimize negative externalities of escaped, farmed salmon - limited liability regulations, low fractional reserve ratios, interest rate ceilings and deregulated commodity markets. The discourse can be further highlighted by the following statements.

Statement XIX, by Fiske et. al (2006:1): Our results indicate a significant positive correlation between the incidence of escaped farmed salmon in the rivers at the county level and the intensity of salmon farming, measured by the number of farmed salmon in net pens, suggesting that protection areas may reduce the impact of escapees in salmon populations nearby.

Statement XX, by Torstein Moland, Executive Chair NJFF 9 (Natur og Miljø 2011: 3): I acknowledge the farming of salmon as a permanent Norwegian industry. However, we demand that the industry makes an effort to put the entire farming system in land based cages. Until this shift of technology has taken place, we also demand that the government imposes serious environmental sanctions and fees on actors that commit negative externalities on wildlife.

Statement XXI, by Espen Farstad, communication officer NJFF (personal communication 05/05/2011): We do not intend to force the sea farming industry out of business - but we want a clear distinction between farmed salmon, which need to be in land based systems, and wild salmon. We would like to work together with both the industry and the government to speed up the process of this shift.

By distinguishing between farmed/domestic salmon and wild salmon, one inadvertently agrees that there is such a thing as the "wild". The concept of "wild fish" is applied inter-discursively, probably without regard to its actual connotations. Groups defending a first nature discourse conclude that there is a difference between the wild and the modified - between first nature and second nature:

Statement XXII, by Knut Mørkved and Frode Staldvik (Dagens Nœringsliv 27/10/2010): The salmon population of each river has unique genetic compositions... Nature has composed a perfect genetic system... If humans alter a system - the effects are always negative. The escaped farmed salmon destroy this genetic variability of wild salmon.

Bacteria, viruses and parasites do not originate from farmed fish, however domesticated animals are particularly susceptible to pathogens since they are raised in high densities, even if the pathogens come from external sources. Sea farmed salmon can succumb to disease before they are grown out and ready for processing. The mortality rate has been relatively stable over the last 15 years at about $20 \%$ (Gullestadutvalget 2011). Whether this could be labeled a continuous epidemic or not is rarely discussed. In other farming contexts, epidemics certainly evolve primarily out of high-density practices (McNeill 1976).

The Norwegian Seafood Federation (FHL) in their information pamphlet Sea Farming Facts includes the following statements:

Statement XXIII: Sea lice occur naturally.

Statement XXIV: Wild salmon can bring sea lice from the ocean. (FHL 2011)

The language suggests a first nature adaptation, because "naturally" as well as "wild" have first nature connotations. Biologists emphasize that sea lice become more aggressive and proliferate with high salmon densities, including the net-pens (Mennerat et al. 2010). From a first nature discourse, the sea lice problem in several Norwegian fjords is deemed unnatural, even though sea lice are natural. The FHL interpret nature as external to human activities by describing non-farmed salmon as wild. But their assumption in supporting sea farming is that nothing is really wild. The distinction is hard to communicate.

Some actors defending a first nature discourse support a "preservation as last resort argument". They consider totalitarian preservation of certain areas as the only way to create geographical places devoid of industrial practices. Rather than fighting for revitalizing traditional fisheries, they accept the farming of Atlantic salmon as a major industry, but still advocate for the exclusion of the same industry from specific areas. As an example of such "last resort" rationales, in the quote below that one important member of a government party goes further in her internal critique than most of her colleagues. This shows that there is actually more than one discourse represented in governmental offices. But she is careful not to make

\footnotetext{
${ }^{9}$ NJFF is the abbreviation for the Norwegian Organization of Hunters and Anglers.
} 
statements about what remedies are needed. She merely announces that the government has failed in the short term.

Statement $X X V$, by Heidi Sørensen, State Secretary, Ministry of Environmental and Development Affairs (Hardangerfjordseminaret, Øystese 05/05/2011): Biological pollution, such as the diffusion of infectious disease, is the worst kind of pollution because of its proliferating effects, causing the extinction of habitats. The government is not even close to accomplishing the goals of the Strategy for an Environmentally Sustainable Norwegian Aquaculture Industry.

Statements such as the one above exhibit the reactive logic common in arguments emerging from first nature discourses. The severity of negative externalities is explicitly acknowledged, but structural change to alter existing paths is passed over.

\section{The traditionalist discourse}

Statement XXVI, Frode Strønen, coastal fisherman and founder of the non-farmed fish enterprise Fiskfråfjorden (www.pelletssei.no, 2010): Norwegian fisheries need to unite and protest against the fact that the central government and the salmon farming industry in all possible ways hurt and destroy resources that constitute the entire livelihood of ordinary fishermen. The fjords are destroyed now.... The Coalfish we depend on is inedible due to feces and poisonous feed spills from salmon farms. ${ }^{10}$

There is obviously no exact foundation to define the origin of a traditional practice. One might ask questions such as: what is the baseline of modernity? Was a traditional practice modern when it originated? How do we know that progress does not lead to retrogression? And so on. Questions of this kind create false dichotomies between the past and future, and involve a logically unsound nostalgia for older practices (Halfacree 1997; Murdoch et al. 2003). Traditional practice may equate with sustainability in its true form, refering to robustly performed practices with easily redeemable negative externalities. Historical data suggest calamitous negative externalities from domestication of new animal species (McNeill 1976; Diamond 1997). Jerry Mander notes "What is needed... is the ability to understand the benefits and drawbacks of new technologies before they overtake us" (1991:107). In traditionalist language, externalities might be avoided with a more moderate approach in the adaptation of new innovation.

In a traditionalist discourse it is implied that human beings can obtain understanding of nature's fluctuations that is not conveyed by language, but captured in their embodied experience - in accord with Polanyi's tacit knowledge and Taleb's advocacy for tacit skills to develop robust resource extraction practices (Polanyi 1962; Taleb 2007). Those expressing a traditionalist discourse don't perceive the world $a$-priori as one where scarcity, marginalization and epidemics are necessary attributes of human endeavors. The misanthropic determinism of Malthus and neo-Malthusians like Garrett Hardin (1968) is rejected, suggesting that humans can execute long-term, robust livelihoods in a non-scarcity world. The following statement is an explicit lament emerging from a traditionalist discourse.

Statement XXVII, by Rune Jensen, secretary general of Salmon Camera (Hardangerfjordseminaret, Øystese 05/05/2011): We have enough science now. The industry uses arguments of more science to postpone rectifications of the serious problems we have. What we need is to change the entire business. The money that goes into science should rather go to establishments of local, traditional fishermen who fight for survival as salmon farming contaminates their livelihoods.

The main difference with the first nature discourse is the fuller questioning of activities with higher input than output. A transformative rather than reactive logic is applied. An integration between economic activities and nature is sound when performed in alignment with actors' self-regulating, experience based harvesting:

Statement XXVIII, by Norges Kystfiskarlag (www.norgeskystfiskarlag.no 05/10/2010): The Hardangerfjord traditional fishery has suffered substantial economic losses due to the reduced quality of Coalfish due to feed spills stemming from the large numbers of salmon farming production units in the fjord.

\footnotetext{
${ }^{10}$ Coalfish, or Pollachius, is generally known as coley in the UK and pollock in North America.
} 
Statement XXIX, by Tor Mikkola, Fjordfiskernes Forening (TV2 24/08/2011): Salmon farming is a disaster legitimized by politicians... I haven't heard any coastal fishers claiming that salmon farming is not destructive to their livelihood... Salmon farming is hurting traditional fisheries through feces and dirty fjords.

Some people argue that non-domesticated fish are of higher quality. It is hard to establish empirical data on fish quality. The tacit dimension of the traditionalist discourse is therefore important, for example by circumventing "the tragedy of the commons" when relying on fishermens' implicit understanding of changes in weather, sea water temperature, populations of predators, unstable length of growing seasons and so on.

Statement XXX, by Nordland Fylkesfiskarlag (NRK 23/09/2010): Salmon farming is making it increasingly more difficult for traditional fisheries to deliver healthy products to consumers. Aquaculture is therefore pushing much of the traditional fishery out of business.

In Nordland, the fastest growing sea farming region of Norway, vandalism against new salmon farming production units has occurred. Several incidents have resulted in court cases between salmon farming companies and those municipalities that do not welcome the presence of salmon farms. And also:

\begin{abstract}
Statement XXXI, by Nordlands Fylkesfiskerlag, (www.fish.no 27/09/2011): It is common knowledge that farmed salmon have sea lice problems and that different medicines and poisons are utilized for delousing. It is also known that sea lice and other pathogens have developed resistance to the most commonly applied medicines, such as antibiotics - and new forms of poison are gradually applied to combat pathogens. One of these substances is flubenzuron. Flubenzuron is a chemical substance that stops the effect of the enzyme kitinase, which dissolves kitin. This process is a precondition for shellfish to be able to change their shells, and the animals die if they are unable to change their shell. This is how sea lice are killed. However, unintentionally, other organisms are also killed, particularly shellfish.

Statement XXXII, by Nils Pettersen, Executive Chair of the Organization of Norwegian Salmon Rivers (official press release 12/04/2010): The growth of the salmon farming industry must stop to save returning Atlantic salmon habitats. Some 3,000 employees in salmon angling might lose their jobs if the government does not change the salmon farming industry... Continued growth of the industry cannot be accepted until the problems of sea lice and escape are proved to be solved.
\end{abstract}

Groups defending the traditionalist discourse apply tangible and intangible (esoteric) values. The expedient logic of high turnover arguments is criticized by Bartov et al. as suboptimal for the autonomy of affected localities and individuals (2002). Even long-term shareholder capitalists like Roger Martin have raised concerns (Martin 2011). Although the value of knowing that an activity causes reduced quality of the end-product are difficult to quantify, traditionalists argue their case strongly. Callicot labels such perceptions as "Utiltarian Conservationism", where actors conserve the environment for long-term economic activities rather than for the value of pristine "nature," or for recreation (or they consider the terms inseparable, in holistic terms) (Callicot 1989).

\title{
7. Deconstructing discourses
}

There are important philosophical debates about the value of the different discourses presented here. Richard Sylvan (1973) stressed the intrinsic value of the non-human, natural world, which requires a form of biological realism that recognizes it. There are risks that if allowing a disconnection to the real world, meaning will be reduced to the smallest common denominator of value, the present monetary value of commoditized goods (Lyotard 1984; Phillips 2003; Žižek 2010). This is a risk for salmon farming, where fish are increasingly traded through derivatives markets (i.e. separated from their physical attributes), where externalities and quality are omitted from capital trading. Again in political ecology analysis, there are disagreements over the extent to which discourses reflect, or float free from, real and concrete environmental phenomema and how useful they are to reveal belief and values (Demeritt 1994, 1998, 2001; Robbins 2004; Sullivan 2000; Woolgar 1988).

\section{The value systems of human/nature relations}

Interpretations of what nature is and the discourses that follow from these interpretations can result in diverging perceptions of otherwise identical events (for example a given negative externality). It is plausible to distinguish between three diverging interpretations of the relationship between humans and nature (Buijs et al. 2010; Uggla 2010): 
- Anthropocentric: humans are a part of nature, but stand above all other species. Humans should utilize nature instrumentally;

- $\quad$ Ecocentric: humans stand above nature. We have a responsibility to keep some nature devoid of human influence, and

- $\quad$ Biocentric: there is no distinction or hierarchy between nature and humans.

The four discourses of salmon farming relate directly to the above interpretations. A high turnover discourse employs anthropocentric arguments, whereby increased, short-term utility for a limited group of human beings is the sole variable of importance. A first nature discourse, on the other hand, manifests an ecocentric interpretation, where humans are perceived to stand above nature, yet with a responsibility to "save" nature from economic activities. A traditionalist discourse emerges from a biocentric interpretation, in which humans are perceived to be an integral part of nature (Uggla 2010).

It is clear that the interpretations contradict one another in the biological/ontological and the ethical interpretation of human-nature relations. Interestingly, arguments emerging from the technology-optimism discourse include elements from all value systems, exhibiting contradictory narratives within seemingly coherent interpretations, in what Bateson et al. label "double binds" (1956). Double binds are the inevitable consequence of incompatible intentions or promises.

\section{Interdiscursivity and strategic framing}

In The construction of social reality (1995), John Searle makes an important distinction between epistemic and ontological objectivity. The former refers to something whose truth can be discovered and evaluated by any interested party, for example the current price of farmed salmon on derivatives markets. The latter describes the underlying realities of the world, such as mechanisms that produce virulent pathogens. A major trouble in society is that many laypeople and academics conflate the two kinds of objectivity. Writers who describe the "genesis" of every discourse as equally arbitrary commit the epistemic fallacy: concluding from the fact that actors are incapable of capturing the complete ontological dimensions of externalities of economic actions, that there is no such thing as ontological externalities of economic actions (Bhaskar 1994; Fairclough et al. 2002).

Some discourses are more embedded in international discourses that others, yet no discourse is inseparable from both ontological and epistemological dimensions. It follows that the main arguments of the respective discourses are not necessarily equal in terms of their approximate truth-value (or lack thereof) (Sayer 2000). The goal of critical discourse analysis is thus to transcend both the ontic and the epistemic fallacy, as explained by Fairclough et al. (2002:5);

Just because the relation of reference between individual lexemes or phrases and objects to which they refer is not one-to-one or self-sufficient, it does not follow that language and ways of thinking are unconstrained by the world. Not just anything can be constructed. This does not mean that the differentiations and qualities of the world dictate the content of knowledge - for the latter is a fallible construction and to assume otherwise is to commit the ontic fallacy. But nor is the world or being dependent on knowledge - if one assumes that it is, one commits the epistemic fallacy.

In language, interdiscursivity occurs both with and outside deliberate framing. The former is also known as strategic framing. The latter constitutes so-called overdetermination, i.e. when actors unknowingly convey arguments from contradictory discourses (Hitching et al. 2011). The most evident example of overdetermination is the interdiscursive application of the concept of wild fish. Consequently, actors might apply the language of different discourses dependent on the arena in which they speak, inadvertently adjusting to the appropriate discourse of the medium. Wild fish clearly emerges from a first nature discourse, yet is nevertheless employed even by actors who believe that there is no such thing as the "wild."

One evident example of strategic framing is the concept of sustainability. It is interpreted in diverse ways, such that "people may learn new discourses and use them for certain purposes..." (Fairclough 2005:82) Sustainability is usually applied with total disregard to its actual implications.

Top-down concepts such as sustainable development are reduced to "...political technologies for continuing environmentally destructive resource extraction and undermining contestation" (Fløysand, Haarstad and Barton, 2010:203). As Nietzsche concluded in Twilight of the Idols, "Even the most courageous among us only rarely has the courage for that which he really knows" (Nietzsche 1982:466). The interdiscursive application of sustainability has become a tool for strategic framing of environmental policies with little or no effect: so-called greenwashing. Lisbeth Berg-Hansen (Norwegian Minister of Fisheries and Coastal Affairs, 2009-), repeatedly speaks about the contemporary and future environmental sustainability of the salmon farming industry. She also repeatedly acts contrary to the original definition of sustainability 
through her acceptance of parallel growth of the industry and increased levels of negative externalities. The inherent contradiction between Ms. Berg-Hansen's speech on the one hand and her actions on the other signals that sustainability in this context has become an interdiscursive and possibly meaningless concept, even having despite explicit, tangible goals. The Minister is hardly dedicated to bringing the original goals of sustainability to life, as it would put her in recurrent and agonizing "double bind" positions (Bateson et al. 1956). Few people like to unravel their internal contradictions. Both "wild fish" and "sustainability" have become hegemonic concepts, albeit with opposite implications. The concept of "wild fish" is fortified through an interdiscursive application of overdetermination by actors, while the concept of "sustainability" is subjected to inflation, and consequent erosion, due to its strategic framing. Jerkø (2009) concludes this in an article that demonstrates discrepancies between the signifier (law) and signified (practice) of sustainability in Norwegian aquaculture. Drawing logically from the premises of each discourse, I suggest the divergent concepts of sustainability shown in Table 1.

\begin{tabular}{|l|l|}
\hline Discourse & Understanding of sustainability \\
\hline $\begin{array}{l}\text { High turnover } \\
\text { discourse }\end{array}$ & $\begin{array}{l}\text { The concept of sustainability is meaningless, as human beings, animals, plants and } \\
\text { everything on earth one day will go extinct and the sun will quit shining. Solar } \\
\text { systems are continuously disrupted. Sustainability is negated by definition, as we } \\
\text { have to adapt to a fundamentally unsustainable world. }\end{array}$ \\
\hline $\begin{array}{l}\text { Technology optimism } \\
\text { discourse }\end{array}$ & $\begin{array}{l}\text { A practice is sustainable so long as human beings have, or are about to reveal, } \\
\text { technological remedies and improvements to combat the symptoms of that } \\
\text { economic activity. }\end{array}$ \\
\hline First nature discourse & $\begin{array}{l}\text { The only sustainable practice is to exclude economic activities from the region in } \\
\text { question. }\end{array}$ \\
\hline Traditionalist discourse & $\begin{array}{l}\text { Sustainable, economic activities are those that can be conducted over the long term } \\
\text { without technological fixes requires to combat symptoms. }\end{array}$ \\
\hline
\end{tabular}

Table 1: How the logic behind discourses links to the concept of sustainability.

\section{A parsimonious realist turn: analysis of negative externalities and the soundness of arguments that emerge from the respective discourses}

Interestingly, large corporations argue that negative externalities are a greater problem among small, locally owned companies, whereas small, locally owned companies argue that the problem is greater where decision-making is centralized (Marine Harvest 2011). Moreover, there are different forms and degrees of negative externalities, implying that different types of grow-out sites could generate different environmental problems. Externalities are mostly specific to places. Currently the west-coast fjords of Norway have high concentrations of production sites in relatively closed fjords. The main distinction is not only between the ownership structures of grow-out sites, but between their physical location, the physical construction of net pens, and how well they are surveyed.

The question is how externalities are perceived. Even in the critical realist tradition, it is acknowledged that "even if we stumble on the truth, that is, we gain some knowledge of the real world, then by what means can we adjudicate that our experience accords with the objective reality?" (Philip 1995:28). Researchers can make high quality observations of biological regularities. However Yeung notes that "...if there is an ultimate truth or theory (be they derived from empirical regularities or whatsoever), science will be impossible because it is either perfect or meaningless" (1997:54). But epistemological generalizations provide insights that should inspire more rather than less regard for present, scientific conclusions.

Solid generalizations of biological regularities are possible, for example on the increased virulence of diseases and parasites in domesticated, dense animal populations (Dobyns 1983), even if epistemological generalizations are harder to make. Beck (1995) argues that the negative externalities of an industry will be prolonged until the market reaches a point of "ecological expropriation", where the value of investments fall only when the market understands its lack of sustainability. So, actors may be victims of an epistemic fallacy until the clear and present danger is forced upon them. But is Beck's insight applicable if the short term logic of limited liability shareholders is increasingly fortified (Bartov et al. 2002)? Rather than redeeming "ecological expropriations", problems affecting profitability (like keeping salmon free of pests) are simply moved to new and less blemished spots - a solution well-known to human geographers as the "spatial fix".

Beck notes "... one side has to prove what it can never prove, in order to be given a hearing: conversely, and on the basis of the same unprovability of consequences of their actions, the other side can do as it pleases... systemic unprovability guarantees that the culprits will never be convicted" (Beck 1995:159). 
In the Norwegian fish processing industry, it took decades from the moment when the evidence of serious economic negative externalities emerged, until the market actually absorbed that information (Jacobsen 2000).

Discourses, as I have argued, need to address the ontologically objective dimension of the problem. Veterinary science, for example, observes that every time a dense animal population is placed in the same area over a long period of time, pathogens build up (Børresen 1995; Jansen et al. 2012; McNeill 1976). Mennerat et al.'s study (2010) identifying the correlation between aggressive sea lice and sea farming is supported by Jansen et al. (2012) and Hamilton et al. (2005) who confirm the causal relationship between density of salmon populations and disease. These statements address these findings:

Statement XXVIII, by the Norwegian Scientific Council for Salmon Management (Status for Norwegian Salmon Populations 2011:3): Sea lice and escaped farmed salmon are per 2010 non-stabilized and constitute existential threats to Norwegian salmon. These threats are very likely significant contributors to particularly low levels of populations of returning salmon.

Statement XXVIX, by Eirik Biering and Ketil Skår (Norwegian Veterinary Institute: Fish Health Report 2010): There are some 350 million salmon in net-pens along the Norwegian coast. This is almost 1,000 times more salmon than the returning wild salmon to Norwegian rivers. In 2010 there were 477 production sites for salmon where there was evidence or suspicion of contagious viruses. In addition were a smaller number of bacterial outbreaks. In these numbers, which should be regarded as the minimum of the actual impact, a large number of contagious salmon individuals constitute a substantial danger to wild fish.

What arguments emerge from discourses to deal with these problems? The high turnover discourse follows an adaptive logic, with an unwillingness to make pre-emptive changes. The traditionalist discourse suggests transformation of industrial fish farming. The other two discourses subscribe to arguments of a reactive kind, that are unsound since they do not address the underlying structure of limited liability shareholder capitalism, which necessarily leads to industries such as salmon farming. I argue, therefore, that discourses can be distinguished hierarchically relative to their congruence with biological realities. The arguments of a high turnover discourse and traditionalist discourse follow a sound logic, where actors have to decide which of these worlds they prefer to speak themselves into - one of short term prosperity or one of long term robustness. Arguments emerging from a technology optimism discourse and from a first nature discourse are unsound, as double binds and myths emerge. While the transformative logic of a traditionalist discourse implies radical policy changes in contrast to existing paradigms, no radical change follows from the logic of the other three. Nonetheless, groups defending a first nature discourse defend modest policy changes in terms of protecting large areas from new salmon farming units. A traditionalist discourse challenges existing paradigms more than the others (Table 2).

\begin{tabular}{|l|l|l|}
\hline \multicolumn{1}{|l|}{ Sound } & $\begin{array}{l}\text { High turnover discourse } \\
\text { (adaptive) }\end{array}$ & $\begin{array}{l}\text { Traditionalist discourse } \\
\text { (transformative) }\end{array}$ \\
\cline { 2 - 3 } & $\begin{array}{l}\text { Technology optimism discourse } \\
\text { (reactive) }\end{array}$ & First nature discourse (reactive) \\
\hline & Low & High \\
\hline
\end{tabular}

Table 2: Logic and realism of salmon farming discourses.

\section{Conclusion}

The critical discourse analysis in this article reveals that there is radical divergence in the perception of externalities from Norwegian salmon farming. In other words, what constitutes negative externalities is far from static: neither in terms of how different actors interpret the very same events, nor in the way variables are applied normatively in risk assessments. The analysis deconstructs four discourses: high turnover; technology optimism; first nature, and traditionalist. The premises, arguments and the groups defending respective discourses are summarised in Table 3. Obviously, any attempt to distribute narratives into categories is susceptible to generalizations. 


\begin{tabular}{|c|c|c|c|}
\hline $\begin{array}{l}\text { Discourses on } \\
\text { Norwegian salmon } \\
\text { farming }\end{array}$ & $\begin{array}{l}\text { Groups defending } \\
\text { the discourse }\end{array}$ & $\begin{array}{l}\text { Main premises of the } \\
\text { discourse }\end{array}$ & $\begin{array}{l}\text { Solutions to avoid } \\
\text { negative externalities }\end{array}$ \\
\hline High turnover discourse & $\begin{array}{ll}\text { Individual } \\
\text { representatives } \\
\text { from the } \\
\text { aquaculture sector } \\
\text { - } \\
\text { Aquaculture } \\
\text { newspapers }\end{array}$ & $\begin{array}{ll}\text { - } & \text { Humans have } \\
\text { always altered and } \\
\text { modified the world } \\
\text { - } \\
\text { Survival of the } \\
\text { fittest } \\
\text { - } \\
\text { Anthropocentric } \\
\text { interpretation of } \\
\text { nature }\end{array}$ & $\begin{array}{ll}\text { - } & \text { Solutions to } \\
\text { externalities are not } \\
\text { important and will } \\
\text { emerge when } \\
\text { needed } \\
\text { - } \\
\text { Adaptive and } \\
\text { expedient logic }\end{array}$ \\
\hline $\begin{array}{l}\text { Technology optimism } \\
\text { discourse }\end{array}$ & $\begin{array}{ll}\text { - } & \text { Central } \\
& \text { government } \\
\text { - } & \text { Parliamentary } \\
& \text { representatives } \\
\text { - } & \text { Mainstream } \\
& \text { scientific } \\
\text { - } & \text { community } \\
& \text { Formalized } \\
& \text { aquaculture } \\
& \text { organizations }\end{array}$ & $\begin{array}{ll}\text { - } & \text { 'Golden mean' } \\
& \text { solutions exist } \\
\text { - } & \text { Linear } \\
\text { development of } \\
\text { civilization over } \\
\text { time } \\
\text { - New technologies } \\
\text { circumvent 'double } \\
\text { binds' } \\
\text { - Mixed } \\
\text { interpretations of } \\
\text { nature }\end{array}$ & $\begin{array}{ll}\text { - } & \text { Solutions will come } \\
\text { with future } \\
\text { technologies } \\
\text { - } \quad \text { Reactive/incentive } \\
\text { based logic } \\
\text { - } \quad \text { Codified knowledge }\end{array}$ \\
\hline First nature discourse & $\begin{array}{ll} & \text { Wild salmon } \\
\text { organizations } \\
\text { - } & \text { Individual salmon } \\
& \text { anglers } \\
\text { - } & \text { Environmental } \\
\text { organizations }\end{array}$ & $\begin{array}{ll}\text { - } & \text { Modified nature is } \\
\text { - } & \text { not nature } \\
\text { - } & \text { itself } \\
\text { Preserve nature } \\
\text { from economic } \\
\text { activities } \\
\text { - Ecocentric } \\
\text { interpretation of } \\
\text { nature }\end{array}$ & $\begin{array}{l}\text { - } \quad \text { Create specific areas } \\
\text { where salmon } \\
\text { farming is allowed - } \\
\text { and specific areas } \\
\text { where salmon } \\
\text { farming is banned } \\
\text { - } \quad \text { Reactive/exclusion } \\
\text { based logic }\end{array}$ \\
\hline Traditionalist discourse & $\begin{array}{l}\text { The marginalized } \\
\text { natural resource } \\
\text { professions } \\
\text { (traditional } \\
\text { fisheries) } \\
\text { - } \text { Quality food } \\
\text { movements } \\
\text { - Some } \\
\text { municipality } \\
\text { officials } \\
\end{array}$ & $\begin{array}{ll}\text { - } & \text { Flourishing } \\
\text { communities can } \\
\text { only be achieved } \\
\text { through long-term } \\
\text { robust methods of } \\
\text { resource extraction } \\
\text { - } \\
\text { Biocentric } \\
\text { interpretation of } \\
\text { nature }\end{array}$ & $\begin{array}{ll}\text { - } & \text { Substitute salmon } \\
\text { farming with a } \\
\text { revitalization of } \\
\text { traditional fishery } \\
\text { practices } \\
\text { - } \quad \text { Transformative } \\
\text { logic } \\
\text { - } \quad \text { Tacit knowledge }\end{array}$ \\
\hline
\end{tabular}

Table 3: Summary of discourses.

This article has broken new ground by evaluating the coherency of implicit, discursive arguments in fish farming. It offers new insights into how the logic of a discourse corresponds with the reality of underlying economic structures and environmental conditions. The findings, although specific to discussions on Norwegian salmon farming, are transferable to all kinds of contemporary food production: particularly in high-density production systems or where derivative markets operate. To reiterate the findings;

- A reactive approach to negative externalities, evident in a technology optimism discourse and first nature discourse, exhibits "double binds", ignoring underlying economic structures such as debt aggregation from fractional reserve banking and limited liability regulations. These lead inevitably to negative environmental externalities - debt in another form. 
- An adaptive logic, evident in a discourse stressing high financial turnover, explicitly acknowledges the underlying economic structures of a global society, and actors subscribing to this logic endorse these structures.

- The transformative logic of traditionalist arguments, on the other hand, implies a society of completely altered institutions around fish farming. The misanthropic determinism of Malthusian scarcity is rejected here, with its language and in practice. It suggests that humans can execute long-term, robust livelihoods.

\section{References}

Aarset, B. and Jakobsen, S.E. 2008. Political regulation and radical institutional change: the case of aquaculture in Norway. Marine Policy 32(2): 280-287.

Adger, W.N., Benjaminsen, T.A. Brown, K. and Svarstad, H. 2001. Advancing a political ecology of global environmental discourses. Development and Change 32(4): 681-715.

Aslesen, H.W., Mariussen, A., Olafsen, T, Winther, U., and Ørstavik, F. 2002. Innovasjonssystemet i norsk havbruksnæring. STEP report 16/2002. Oslo. STEP.

Bartov, E., Givoly, D. and Hayn, C. 2002. The rewards to meeting or beating earnings expectations. Journal of Accounting and Economics 33(2): 173-204.

Bateson, G., Jackson, D.D., Haley, J. and Weakland, J. 1956. Toward a theory of schizophrenia. Behavioral Science 1: 251-264.

Benjaminsen, T.A. and Svarstad, H. 2010. Politisk økologi: miljø, mennesker og makt. Oslo: Universitetsforlaget.

Beck, U. 1992. Risk society: towards a new modernity. London: Sage Publications.

Beck, U. 1995. Ecological politics in an age of risk. Cambridge: Polity Press.

Berg, M. 1986. Det norske lakse- og innlandsfiskets historie. Oslo: Universitetsforlaget.

Berge, D.M. 2002. Dansen rundt gullfisken: nceringspolitikk og statlig regulering i norsk fiskeoppdrett 19701997. PhD dissertation. University of Bergen: Department of Administration and Organizational Science.

Berkes, F. 1999. Sacred ecology: traditional ecological knowledge and resource management. Philadelphia: Taylor and Francis.

Bhaskar, R. 1994. Plato etc.: the problems of philosophy and their resolution. London: Verso.

Blaikie, P. 1989. Explanation and policy in land degradation and rehabilitation for developing countries. Land Degradation and Rehabilitation 1: 23-37.

Blaikie, P. 1996. Post-modernism and global environmental change. Global Environmental Change 6(2): 8185.

Blaikie, P. 1999. A review of political ecology: issues, epistemology and analytical narratives. Zeitschrift für Wirtschaftsgeographie 43(3-4): 131-147.

Blaikie, P. 2001. Social nature and environmental policy in the South: views from the verandah and veld. Castree, N. and Braun, B. (eds.) Social nature: theory, practice and politics. Oxford: Blackwell.

Bourdieu, P. 1977. Outline of a theory of practice. Cambridge: Cambridge University Press.

Brox, O. 1989. Kan bygdencringene bli lønnsomme? Oslo: Gyldendal.

Buijs, A.E., Arts, B.J.M., Elands, B.H.M. and Lengkeek, J. 2011. Beyond environmental frames: the social representation and cultural resonance of nature in conflicts over a Dutch woodland. Geoforum 42(3): 329-341.

Børresen, B. 1995. Husdjuren och deras människor: folk och fä under 18000 år. Stockholm: Raben Prisma.

Callicott, J. B. 1989. American Indian land wisdom? Sorting out the issues. Journal of Forest History 33(1): 35-42.

Castree, N. 2005. Nature. London: Routledge.

Castree, N. 2008. Neoliberalising nature: the logics of deregulation and reregulation. Environment and Planning A 40: 131 - 152.

Demeritt, D. 1994. Ecology, objectivity, and critique in writings on nature and human societies. Journal of Historical Geography 20 (1): 22-37.

Demeritt, D. 1998. Science, social constructivism and nature. In Braun, B. and Castree, N. (eds.) Remaking reality: nature at the millennium. New York: Routledge. Pp173-193.

Demeritt, D. 2001. The construction of global warming and the politics of science. Annals of the Association of American Geographers 91(2): 307-337.

Diamond, J. 1997. Guns, germs, and steel: the fates of human societies. New York: W.W. Norton. 
Diserud, O.H., Fiske, P. and Hindar, K. 2010. Regionvis påvirkning av rømt oppdrettslaks på ville laksebestander i Norge. NINA Rapport 622.

Dobyns, H. 1983. Their number became thinned. Knoxville: University of Tennessee Press.

Elliot, R. 1982. Faking nature. Inquiry 25: 81-93.

Elster, J. 2009. Excessive ambitions. Capitalism and Society 4(2): 1-30.

Fagerberg, J., Mowery, D.C. and Verspagen, B. 2009. Introduction: innovation in Norway. In Fagerberg, J., Mowery, D.C. and Verspagen, B. (eds.) Innovation, path dependency and policy. The Norwegian case. Oxford: Oxford University Press. Pp1-29.

Fairclough, N. 1995. Critical discourse analysis: the critical study of language. London, New York: Longman.

Fairclough, N., Jessop, B. and Sayer, A. 2002. Critical realism and semiosis. Journal of Critical Realism 5(1): 2-10.

Fairclough, N. 2003. Analysing discourse: textual analysis for social research. London: Routledge.

Fairclough, N. 2005. Critical discourse analysis. Marges Linguistiques 9: 76-94.

Fiske, P., Lund, R. A. and Hansen, L. P. 2006. Relationships between the frequency of farmed Atlantic salmon, Salmo salar L., in wild salmon populations and fish farming activity in Norway 1989-2004. ICES Journal of Marine Science 63(7): 1182-1189.

Fløysand, A., Haarstad, H. and Barton, J. 2010. Global economic imperatives, crisis generation and local spaces of engagement in the Chilean aquaculture industry. Norwegian Journal of Geography 64: 199210.

Franzen, J. 2010. Freedom. London: Fourth Estate.

Glacken, C. J. 1967. Traces on the Rhodian shore: nature and culture in western thought from ancient times to the end of the eighteenth century. Berkeley: University of California Press.

Halfacree, K. 1997. Postmodern perspectives on counterurbanization. In Cloke, P. and Little, J. (eds.) Contested countryside cultures: otherness, marginalisation and rurality. London: Routledge. Pp 70-93.

Hamilton, M.C., Hites, R.A., Schwager, S.J., Foran, J.A., Knuth, B.A. and Carpenter, D.O. 2005. Lipid composition and contaminants in farmed and wild salmon. Environmental Science and Technology 39(22): 8622-8629.

Hanley, N., Shogren, J. and White, B. 2007. Environmental economics in theory and practice. 2nd Edition. London: Palgrave.

Hardin, G. 1968. The tragedy of the commons. Science 162(3859):1243-1248.

Harvey, D. 2010. The enigma of capital. London: Profile Books.

Hesse, C. and MacGregor J. 2006. Pastoralism: drylands' invisible asset. Developing a framework for assessing the value of pastoralism in East Africa. IIED Issue Paper 142.

Hitching, R. R., Nilsen, A. B., Veum, A. 2011. Diskursanalyse i praksis. Metode og Analyse. Oslo: Norwegian Academic Press.

Hodgson, G. 2006. What are institutions? Journal of Economic Issues XL(1):1-25. http://www.geoffreyhodgson.info/user/bin/whatareinstitutions.pdf

Hulme, M. 2010. Problems with making and governing global kinds of knowledge. Global Environmental Change 20(4): 558-564

Jakobsen, S-E. 2000. Knowledge, informal rules and localised competitiveness: a study of a local milieu in the Norwegian fish processing industry. Bergen: Foundation for Research in Economics and Business Administration.

Jansen P.A., A.B. Kristoffersen, H. Viljugrein, D. Jimenez, M. Aldrin and A. Stien. 2012. Sea lice as a density-dependent constraint to salmonid farming. Proceedings of the Royal Society B in press.

Jerkø, M. 2009. Det norske formålet "bærekraftig utvikling". Tidsskrift for Rettsvitenskap 3: 354-387.

Johansson, O.A. 2004. Konsten att framställa foder till laxfisk. Om teknologisk innovation. Masters Thesis. Department of Sociology and Human Geography. Norway: University of Oslo.

Knight, F. H. 1921. Risk, uncertainty and profit. Boston, MA: Hart, Schaffner and Marx.

Liu, Y., Olaussen, J.O. and Skonhoft, A. 2010. Wild and farmed salmon in Norway - a review. Marine Policy 35(3): 413-418.

Liebowitz, S.J. and Margolis, S.E. 1995. Path dependence, lock-in, and history. Journal of Law, Economics, and Organization, 11(1): 205-226.

Lyotard, J.F. 1984. The postmodern condition: A report on knowledge. Minneapolis: University of Minnesota Press. 
Maddox, G. 2002. Degradation narratives and population time bombs: myths and realities about African environments. In Dovers, S. R. Edgecombe and Guest, B. (eds.): South Africa's environmental history: cases and comparisons. Cape Town: David Philip Publishers. Pp250-258.

Magnussøn, A. 2011. Making food - enactment and communication of knowledge in salmon aquaculture. Ph.D. dissertation. Oslo: University of Oslo.

Mandelbrot, B and Hudson, R. L. 2008. The (mis)behavior of markets: a fractal view of risk, ruin and reward. London: Profile Books.

McNeill, W. 1976. Plagues and peoples. New York: Doubleday.

Mander, J. 1992. In the absence of the sacred. San Francisco: Sierra Club Books.

Martin, R. 2011. The age of the inauthentic executive: how a dysfunctional community encourages bad behavior. The Magazine of the Rotman School of Management. Spring 2011.

McGuire, T.R. 1997. The last Northern cod. Journal of Political Ecology 4: 41-54.

Mennerat A., Nilsen F., Ebert D. and Skorping A. 2010. Intensive farming: evolutionary implications for parasites and pathogens. Evolutionary Biology 37(2-3): 59-67.

Murdoch, J., Lowe, P., Ward, N. and Marsden, T. 2003. The differentiated countryside. London: Routledge.

Montgomery, D. 2003. Dirt: the erosion of civilizations. Berkeley: University of California Press.

Needham, T. 1986. The influence of the Norwegian salmon industry on Scotland. Proceedings of international conference, Norway: The development of its fish farming industry. Cork: Sherkin Marin Island Station, Cork.

Nietzsche, F. 1982 [1888]. Twilight of the idols. In Kaufmann, W. (ed) The portable Nietzsche. New York: Penguin Books.

Ostrom, E., Burger, J. Field, C.B., Norgaard, R.B. and Policansky, D.1999. Revisiting the commons: local lessons, global challenges. Science 284(5412): 278-282.

Ostrom. E. 2005. Understanding institutional diversity. Princeton: Princeton University Press.

Philip, P. 1995. Transcendental realism - a foundation for evolutionary economics? International Journal of Social Economics 22(12):19-35

Phillips, R. 2003. The war against pluralism. In Sterba, J. (ed.) Terrorism and international justice. Oxford: Oxford University Press.

Polanyi, M. 1962. Personal knowledge. Chicago: University of Chicago Press.

Poppe, T.T. 2010. Dyrevelferd i fiskeoppdrett? Norsk Veterincertidsskrift 9: 122.

Robbins, P. 2004. Political ecology: a critical introduction. Oxford: Blackwell.

Sayer, A. 2000. Realism and social science. London: Sage.

Searle, J.R. 1995. The construction of social reality. New York: The Free Press.

Searle, J.R. 2010. Making the social world: the structure of human civilization. Oxford: Oxford University Press.

Slovic, P. 1987. Perception of risk. Science 236(4): 280-285.

Smith, N. 1984. Uneven development: nature, capital and the production of space. Oxford: Basil Blackwell.

Smith, N. 1992. Geography, difference and politics of scale. In Doherty, J, Graham, E. and Malek, M. (eds.) Postmodernism and the social sciences. Basingstoke: MacMillan. Pp 57-79.

Stacey, R.D., Griffin, D. and Shaw, P. 2000. Complexity and management: fad or radical challenge to systems thinking? London: Routledge.

Sullivan, S. 2000. Getting the science right, or, introducing science in the first place? In Stott, P. and Sullivan, S (eds.) Political ecology: science, myth, and power. New York: Arnold. Pp14-44.

Sylvan, R. (Routley, F.R.) 1973. Is there a need for a new, an environmental, ethic? In Proceedings of the 15th world congress of philosophy, vol.1. Sophia, Bulgaria: Sophia Press. Pp 205-210. Reprinted in Zimmerman M. et al. (1993) Environmental philosophy: from animal rights to radical ecology. New Jersey: Prentice Hall. Pp.12-21.

Sæther, B. 1999. Regulering og innovasjon: miljøarbeid I norsk treforedlingsindustri 1974-1998. Ph.D. dissertation. Oslo: University of Oslo.

Taleb, N.N. 2007. The black swan: the impact of the highly improbable. London: Penguin Books.

Taranger, G.L. et al. 2010. Risikovurderinger - miljøvirkninger av norsk fiskeoppdrett. Fisken og Havet, særnummer 3-2010. Bergen: Institute of Marine Research.

Thomas, W.I. and Thomas, D.S. 1928. The child in America: behavior problems and programs. New York: Alfred A. Knopf

Tveterås, R. 2002. Industrial agglomeration and production costs in Norwegian salmon aquaculture. Marine Resource Economics 17(1): 1-22. 
Uggla, Y. 2010. What is this thing called 'natural'? The nature-culture divide in climate change and biodiversity policy. Journal of Political Ecology 17: 79-91.

Watts, M.J., Robbins, P. and Peet, R. (eds.) 2010. Global political ecology. London: Routledge.

Weber, M. 2011 [1905]. The Protestant ethic and the spirit of capitalism. New York: Oxford University Press. Woolgar, S. 1988. Science: the very idea. London: Tavistock.

Yeung, H.W.C. 1997. Critical realism and realist research in human geography: a method or a philosophy in search of a method? Progress in Human Geography 21(1): 51-74.

Žižek, S. 2010. Living in the end times. London: Verso.

\section{Reports}

Gullestadutvalget, 2011. Effektiv og bcerekrafig arealbruk i havbruksnæringen. Report commissioned by The Ministry of Fisheries and Coastal Affairs. Oslo.

Institute of Marine Research. 2011. Risk assessment: environmental impacts of Norwegian aquaculture. Bergen. August 2011.

Marine Harvest, 2011. Excellence in seafood. Presentation at the Norwegian School of Economics, Bergen. September 15-16, 2011.

Norwegian Ministry of Fisheries and Coastal Affairs. 2009. Strategy for an environmentally sustainable Norwegian aquaculture industry. Oslo: Norwegian Ministry of Fisheries and Coastal Affairs.

Norwegian Ministry of Fishery and Coastal Affairs, 2010. Fakta om Fiskeri og Havbruk.

Norwegian Seafood Federation (FHL). 2011. Sea farming facts. 


\begin{abstract}
The concern of this article is the language and ontology of negative externalities. Four discourses on the financially successful industry of salmon farming in Norway are critically analyzed and deconstructed. The discourses are: "high turnover discourse", "technology optimism discourse", "first nature discourse" and "traditionalist discourse". Groups defending various discourses differ in their interpretations of a) human/nature relations i.e. either ecocentric, anthropocentric or biocentric, and b) in their respective approach to either a transformative, adaptive or reactive logic. By linking interpretations, concepts and logic inherent to these discourses, it is possible to make conclusions on their degree of coherency. The leading discourses are maintained in language through strategic framing and overdetermination. These linguistic mechanisms are revealed in the discursive application of the concepts of sustainability and wild fish. Rather than to surrender to relativism, the article recommends integration of realism and deconstruction.
\end{abstract}

Key words: Atlantic salmon farming, food production, critical discourse analysis, negative externalities, soft constructionism, parsimony, political ecology, sustainability.

\title{
Resumé
}

Le souci de cet article est la langue et de l'ontologie des externalités négatives. Quatre discours sur l'industrie de la salmoniculture en Norvège sont analysées de façon critique et déconstruit. Les discours sont les suivants: «Le discours des hauts rendements financier», «discours optimiste technologique», «discours de la première nature» et «discours traditionaliste». Les gens qui défendent divers discours sont différents dans leurs interprétations suivantes: a) les relations homme / nature, que ce soi. écocentrique, anthropocentrique ou biocentrique, et b) dans leur approche respective à une logique qui est de transformation, d'adaptation ou réactive. En reliant les interprétations, les concepts et la logique inhérente à ces discours, il est possible de tirer des conclusions quant à leur degré de cohérence. Les discours principaux sont maintenus dans la langue par «cadrage stratégique» et «surdétermination». Ces mécanismes linguistiques sont révélés dans l'application discursive des concepts de «durabilité» dans l'industrie, et "poisson sauvage». Plutôt que de se rendre au relativisme, l'article recommande l'intégration de réalisme et de déconstruction du discours.

Mots clés: élevage du saumon de l'Atlantique, la production alimentaire, l'analyse critique du discours, les externalités négatives, constructionnisme «douce», la parcimonie, l'écologie politique, de la durabilité.

\section{Resumen}

Este artículo trata de la lengua y la ontología de las externalidades negativas. Para ello, se descubren críticamente, se analizan y reconstruyen cuatro discursos sobre la industria de las granjas de salmón en Noruega, de éxito económico. Los discursos son: "discurso de alta facturación", "discurso de optimismo tecnológico", "discurso de la naturaleza primero" y "discurso tradicionalista". Los grupos que defienden tales discursos varían en sus interpretaciones de a) relaciones entre humanos y naturaleza, que pueden ser egocéntricas, antropocéntricas o biocéntricas y b) acercamientos a una lógica transformativa, adaptativa o reactiva. Mediante la relación de interpretaciones, conceptos y lógica inherente a estos discursos es posible llegar a determinadas conclusiones en torno a su grado de coherencia. Los discursos más importantes se mantienen con un lenguaje de planeamiento estratégico y sobredeterminación. Estos mecanismos lingüísticos se revelan en la aplicación discursiva de los conceptos de sostenibilidad y pescado silvestre. En lugar de aceptar el relativismo, este artículo recomienda la integración de realismo y deconstrucción.

Palabras clave: Granjas de salmón Atlántico, producción de alimentos, análisis crítico del discurso, externalidades negativas, construccionismo suave, parsimonia, ecología política, sostenibilidad. 